\title{
Analysis of Student Satisfaction Using Online Video Conference Application Based on Usability Criteria
}

\author{
Johan Patrick $^{1 *}$, Dyah Santhi Dewi ${ }^{2}$
}

\author{
${ }^{1}$ Ergonomics and Safety Department of Systems and Industrial Engineering \\ Institute of Technology Sepuluh Nopember Jl. Teknik Kimia, Keputih, Kec. Sukolilo, Surabaya, Jawa Timur 60111, \\ Indonesia. \\ ${ }^{2}$ Agency for the Assessment and Application of Technology, Indonesia \\ *Corresponding author.Email: johantentua@gmail.com
}

\begin{abstract}
The online learning process or e-learning requires students to be able to use various Online Video Conference (OVC) applications such as Zoom, Google Hangout Meet and Microsoft Teams. As with other products, OVC user satisfaction must be the main concern of product development companies so that the product continues to be the choice and use of the user. For this reason, factors that can affect the satisfaction of using the OVC application need to be identified and understood. Unfortunately, currently there are not many studies related to the factors that affect user satisfaction of the OVC application. This study aims to determine what factors affect the satisfaction of users of online video conferencing, especially for users from among students. In this study, user satisfaction OVC will be analyzed from the usability aspect. The variables studied were usefulness, ease of use, ease of learning, perceived enjoyment, accessibility, security, and satisfaction. The results show that the variables usefulness, ease of use, ease of learning, perceived enjoyment, accessibility, and security have a simultaneous effect on user satisfaction.
\end{abstract}

\section{Keywords: OVC, Usability Criteria, Student Satisfaction measurement}

\section{INTRODUCTION}

Information technology has an impact on various aspects of life and covers all fields of science including education. This rapid and unpredictable growth of technology has led to the emergence of many approaches aimed at the education sector which are manifested in the use of e-learning systems [1]. E-learning also has a very large contribution to changes in the learning process, where the learning process is no longer only listening to material descriptions but also carrying out other activities such as observing, doing, demonstrating and others [2]. The number of e-learning users is almost 25 million users in 2019 [3]. This study counts the number of students who use e-learning as a learning medium. The presence of e-learning in the world of education is a phenomenon in it is self, where with virtual-based technology, it allows e-learning users to learn virtually. This convenience has made e-learning grow rapidly, many websites and applications have sprung up, both those made by educational institutions or non-educational institutions [4].
Non-educational applications that are often used as learning media online are Zoom, Google Meet and Microsoft Teams. In using OVC, there are still some difficulties or complaints. The difficulties experienced when using the OVC application are because users are not familiar with the features of the OVC application, the OVC application is too complex so it is difficult to learn, e-learning does not suit user needs and does not or does not accommodate needs which is important for users [5]. OVC application developers need to pay attention to user satisfaction and understand the factors that influence it, because the success of e-learning applications is characterized by continuous use [6].

E-learning is a learning method or system that utilizes electronic technology and has the advantage that it can be done anywhere and anytime. Time consumption of e-learning is more effective and efficient [7]. According to Gilbert \& Jones (2001) e-learning is the process of delivering learning materials through electronic media 
such as the internet, intranets/extranets, satellite broadcasts, audio/video tapes, interactive TV, CD-ROMs, and computer-based training [8].

Usability comes from the word usable which means it can be used properly. Something can be said to be good if it fails in its use, it can be eliminated or minimized and provides benefits and decisions for its users [9]. Nielsen (2012) in his article entitled "Usability 101: Introduction to Usability" defines, "Usability is a quality attribute that assesses how easy user interfaces are to use"[10]. In other words, usability is a quality attribute that assesses how easy the user interface is to use". So, what is meant by reusability is the quality of a system that is easy to learn, easy to use, and can encourage users or users to use the system effectively and efficiently. ISO 9241-11 (1998) explains that reusability refers to the level of a product that can be used by certain users to achieve specific goals with effectiveness, efficiency and satisfaction in a usage context. The context of use consists of users, tasks, equipment (hardware, software, and materials), and the physical and social environment that affect the usability of the product in the work system. The effect of changing components in the work system can be measured by testing performance and user satisfaction.

\section{METHODS}

\subsection{Questionnaire}

The instrument used in this study was a questionnaire. The questionnaire used to measure usability is a questionnaire that can process data related to effectiveness, efficiency, and satisfaction in using information systems [11]. The underlying reason for using a questionnaire is that it can make it easy for respondents to understand and answer the questions asked correctly. In addition, the questionnaire makes respondents more comfortable and freer to answer questions. In this study using the USE Questionnaire because USE can include three measurements according to ISO, namely efficiency, effectiveness, and satisfaction. USE can include three measurements according to ISO, namely efficiency, effectiveness, and satisfaction. In this study, researchers added variables perceived enjoyment, accessibility, and security.

\subsection{Sample and Population}

This research was conducted in Surabaya, East Java, Indonesia. The respondents of this research were college students in Surabaya. The number of samples is 100 college students.

\subsection{Hypothesis}

This study uses a research design, namely causal design. The aim is to analyze the relationship between the existing variables. Causal design is used to empirically analyze the variables that affect user satisfaction, namely the variables of usability, ease of use, ease of learning, perceived enjoyment, accessibility, security.

Ho: There is a significant influence between variables usefulness, ease of use, and ease of learning, perceived enjoyment, accessibility, and security on the variable satisfaction.

H1: There is a significant influence between the usefulness variables on the satisfaction variable.

$\mathrm{H} 2$ : There is a significant influence between the ease-ofuse variable on the satisfaction variable.

H3: There is a significant influence between the ease of learning variable on the satisfaction variable.

H4: There is a significant effect between the perceived enjoyment variable on the satisfaction variable.

H5: There is a significant influence between the accessibility variable on the satisfaction variable.

H6: There is a significant effect between the security variable on the satisfaction variable

\section{RESULTS AND DISCUSSION}

\subsection{Respondent Characteristics}

In table 1, the gender of the respondents in this study were male as many as 46 people and female as many as 54 people. The data shows that women prefer to use Zoom by 37 people and men prefer to use Google Meet by 15 people. Meanwhile, 9 people used Microsoft Teams and 4 male.

Table 1. Respondent Characteristics.

\begin{tabular}{|l|c|c|c|c|}
\hline & Zoom & $\begin{array}{c}\text { Google } \\
\text { Meet }\end{array}$ & $\begin{array}{c}\text { Microsoft } \\
\text { Teams }\end{array}$ & $\begin{array}{c}\text { Cumula- } \\
\text { tive }\end{array}$ \\
\hline Male & 27 & 15 & 4 & 46 \\
\hline Female & 37 & 8 & 9 & 54 \\
\hline Total & 64 & 23 & 13 & 100 \\
\hline
\end{tabular}

\subsection{Validity and reliability test}

The validity of the instrument is measured based on the validity criteria, if $r$-count $\geq$ r-table then the instrument is declared valid, but if $r$-count $<r$-table then the instrument is declared invalid. It is known that the r-table uses the significant level $\alpha=0.05$ with $n=100$, so the $r$ table value is 0.196 . This means that the data shows the accuracy between the data that actually occurs on the object and the data collected. All criteria are valid $(>0.196)$. A construct or variable can be said to be reliable if it provides a cronbach alpha value $>0.60$. All criteria are reliable because $>0.60$. 


\subsection{Normality Test}

The normality test is a test of the normality of the distribution of the data being tested. The normality test is used to determine whether the data population is normally distributed or not. This normality test is used to measure data on an ordinal, interval or ratio scale. If the analysis uses parametric, then the requirements for normality must be met, that is, the data comes from a normal distribution.

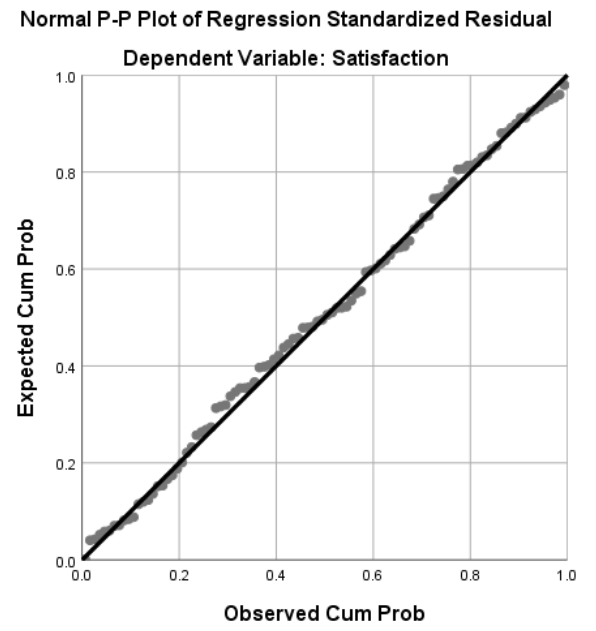

Figure 1. Normal p-plot result.

Based on Figure 1, it can be seen that the plot points always follow and approach the diagonal line, so that as a basis or guideline for decision making in the normality test with the probability plot technique, it can be concluded that the residual value is normally distributed.

\subsection{Heteroscedasticity test}

It can be seen in Figure 2, the dots spread randomly, do not form a certain clear pattern, and are spread either above or below the 0 (zero) number on the $\mathrm{Y}$ axis, so there is no heteroscedasticity.

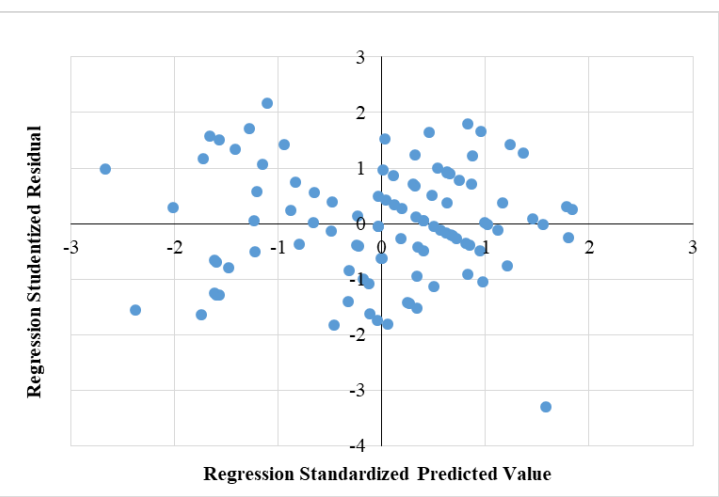

Figure 2. Heteroscedasticity test.

\subsection{Multiple Linier Analysis}

Based on the results of data processing from the usefulness variables, ease of use, ease of learning, perceived enjoyment, security, the regression equation is obtained as follows:

$$
\mathrm{Y}=10.041+0.443 \mathrm{X} 1-0.01 \mathrm{X} 2+0.104 \mathrm{X} 3+0.187
$$

$\mathrm{X} 4+0.066 \mathrm{X} 5+0.105 \mathrm{X} 6$

A constant of 10.041 means that if usefulness, ease of use, perceived enjoyment, accessibility, security do not exist or the value is 0 , then user satisfaction is worth 10.041 .

\subsection{Analysis of the coefficient of determination}

Based on Table 2, below, the R2 (R Square) number is 0.499 or (49.5\%). This shows that the percentage of the contribution of the influence of usefulness, ease of use, ease of learning, perceived enjoyment, accessibility and security on user satisfaction is $49.9 \%$. In other words, the user satisfaction variable can be explained or influenced by the variables usefulness, ease of use, ease of learning, perceived enjoyment, accessibility and security of $49.9 \%$, while the remaining $50.1 \%$ is explained or influenced by other variables not examined

Table 2. A slightly more complex table with a narrow caption.

\begin{tabular}{|c|c|c|c|c|}
\hline Mode & $\mathrm{R}$ & $\begin{array}{c}\mathrm{R} \\
\text { Squa } \\
\text { re }\end{array}$ & $\begin{array}{c}\text { Adjusted R } \\
\text { Square }\end{array}$ & $\begin{array}{c}\text { Std. Error } \\
\text { of the Esti- } \\
\text { mate }\end{array}$ \\
\hline & 0.706 & 0.499 & 0.467 & 1.896 \\
\hline
\end{tabular}

a Predictors: (Constant), Security, Usefulness, Perceived Enjoyment, Accessibility, ease of use, Ease of Learning

\subsection{F-Test}

The results of the f test or simultaneous test be-tween the independent variables (usefulness variables, ease of use variables, and ease of learning, perceived enjoyment, accessibility, security) on the dependent variable (variable satisfaction) can be seen in table 2 .

Based on table. 3, the calculated F-statistics is 15,439 with a Sig value of 0,000 . This shows that the calculated F-statistics is greater than F table 2.2 and the Sig value is less than 0.05. Thus the hypothesis is ac-cepted. This means that ease of use, ease of learning, perceived enjoyment, accessibility, and security togeth-er have a significant influence on student satisfaction in using the OVC application. 
Table 3. F-Test Result.

\begin{tabular}{|c|l|c|c|c|c|c|}
\hline \multicolumn{7}{|c|}{ ANOVA } \\
\hline Model & & Sum of Squares & df & Mean Square & F & Sig. \\
\hline 1 & Regression & 333.067 & 6 & 55.511 & 15.439 & .000 \\
\hline & Residual & 334.373 & 93 & 3.595 & & \\
\hline & Total & 667.440 & 99 & & & \\
\hline
\end{tabular}

a Dependent Variable: Satisfaction

b Predictors: (Constant), Security, Usefulness, Perceived Enjoyment, Accessibility, Ease of Use, Ease of Learning

\subsection{T-statistic test}

The $t$ test is used to determine whether the independent variable partially affects the dependent variable. The results of the $t$ test between the independent variables (variable usefulness, variable ease of use, and ease of learning, perceived enjoyment, accessibility, security) on the dependent variable (variable satisfaction) can be seen in Table 3.

Table 3. T-test Result.

\begin{tabular}{|l|c|c|}
\hline \multicolumn{1}{|c|}{ Model } & $\mathrm{t}$ & Sig. \\
\hline (Constant) & 3.903 & .000 \\
\hline Usefulness & 6.158 & .000 \\
\hline Ease Of Use & -0.168 & 0.867 \\
\hline Ease Of Learning & 0.722 & 0.472 \\
\hline Perceived Enjoyment & 1.369 & 0.174 \\
\hline Accessibility & 0.546 & 0.587 \\
\hline Security & 0.912 & 0.364 \\
\hline
\end{tabular}

Only 1 hypothesis is accepted, Effect of Use-fulness on user satisfaction of online video conferenc-ing. Based on table 3, the t-statistics value is 6.158 with a Sig value of 0.000 . This shows that the t-value is greater than the table value of 1.985 and the Sig value is smaller than 0.05 . Thus, $\mathrm{H} 0$ is rejected and $\mathrm{H} 1$ is ac-cepted. This means that the usefulness variable has a significant effect on student satisfaction in using online video conferencing.

\section{CONCLUSION}

The results showed that the F-count value was 15.439 and the F-table value was 2.2, this means that Fcount> F-table. Then based on the significance test obtained a significance value of 0.000 . Because F- count> F-table and also because of the significance of 0.00 $<0.05$, thus the hypothesis is accepted. This means that ease of use, ease of learning, perceived enjoyment, accessibility, and security together have a significant influence on student satisfaction in using the OVC application. Based on the results of this study, further analysis of the results of hypothesis testing is conducted. Then in the Modal Summary table, where the table displays the correlation coefficient price or relationship (R) and explains the percentage of the influence of the independent variable on the dependent variable called the coefficient of determination which is the result of squaring R.From this output shows that student satisfaction in using the online video application. Conference determined $49.9 \%$ by the variables usefulness, ease of use, ease of learning, perceived enjoyment, accessibility and security, the rest $(50.1 \%)$ is influenced by other variables not discussed in this study. The results of this study support the research conducted by Layla (2020) which states that simultaneously the usability variable affects student satisfaction in using online video conferencing.

\section{REFERENCES}

[1] Harrati, N., Bouchrika, I., Tari, A., \& Ladjailia, A. (2016). Exploring user satisfaction for elearning systems via usage-based metrics and system usability scale analysis. Computers in Human Behavior, 61, 463-471.

[2] Aminoto, T. (2014). Penerapan Media E-Learning Berbasis Schoology Untuk Meningkatkan Aktivitas dan Hasil Belajar Materi Usaha dan Energi Di Kelas XI SMA N 10 Kota Jambi. Jurnal Sainmatika, 8(1).

[3] Lubis, A. H., Idrus, S. Z. S., \& Rashid, S. A. (2020). The exposure of MOOC usage in Indonesia. International Journal of Scientific and Technology Research, 9(2), 2716-2720.

[4] Indhira, B. (2015). Analisa Usability Pada Website Airlangga University E-Learning Application (Studi Deskriptif di Kalangan Mahasiswa Pengguna Website E-learning AULA) Beata

[5] Lestariningsih, T. (2016). Analisis Sitem Informasi Dalam Perspektif Human Computer Interaction. Jurnal AKSI (Akuntansi Dan Sistem Informasi), 1(1), 5-9

[6] Masood, M., \& Musman, A. (2015). The Usability and its Influence of an e-Learning System on Student Participation. Procedia - Social and Behavioral Sciences, 197(February), 23252330. 
[7] Kratochvíl, J. (2013). Evaluation of e-learning course, Information Literacy, for medical students. Electronic Library, 31(1), 55-69.

[8] Gilbert, \& Jones, M. G. (2001). E-learning is e-normous. Electric Perspectives, 26(3), 66-82.

[9] Rahadi, D. R. (2014). Pengukuran Usability Sistem Menggunakan Use Questionnaire Pada Aplikasi Android PENDAHULUAN Interface pengguna Android didasarkan pada manipulasi langsung menggunakan masukan sentuh yang serupa dengan tindakan di dunia nyata, seperti menggesek ( swiping . 6(1), 661-671.

[10] Nielsen, J. (1994). Usability inspection methods. Conference Companion on Human Factors in Computing Systems, 413-414.

[11] Kusuma, W. A., Noviasari, V., \& Marthasari, G. I. (2016). Analisis Usability dalam User Experience pada Sistem KRS Online UMM menggunakan USE Questionnaire. Jurnal Nasional Teknik Elektro Dan Teknologi Informasi (JNTETI), 5(4), 294-301. https://doi.org/10.22146/jnteti.v5i4.277. 